\title{
Sample calculations for the composition of energy performance scales in road lighting reparation
}

\begin{abstract}
At the present, it is in the interest of the majority of most developed countries to reduce the power consumption. Great emphasis is placed on the use of efficient electrical equipment. The European Union started the implementation of the political and economic actions, leading to reduce the use of inefficient products and replacing them with more efficient. Lighting is one of the areas which consumes a lot of energy, but also offers a high potential for savings. Therefore, product- and system-oriented limitations are implemented through European directives into national legislation of the European countries aimed to gradually reduce the use of inefficient products. One of such system tool is the energy performance of buildings introduced several years ago, and now it is time to establish the platform for benchmarking the public lighting systems. In the new draft the standard prEN 13201-5 introduces the compound numerical indicators PDI and AECI. Examples of calculation of the PDI and AECl are in annexes of the draft standard, indicating the typical values for different road profiles, taking into consideration different lighting classes of roads and usage of different technologies available for the public lighting. This paper deals with the extension of the set of calculations and combinations for which the typical parameter values $P D I$ and $A E C l$ are calculated. The main condition for creation of the scales of energy classes it is to have sufficiently large representative sample of model calculations. The main aim of the paper is to propose a scales of energy classes, which will serve as a global comparative model similar to the energy performance of buildings.
\end{abstract}

Keywords: road lighting, energy performance scales, energy efficiency

\section{Introduction}

The Acceptance of uniform parameters for assessing the energy efficiency of public lighting was the first step for possible future certification of the public lighting networks, similarly in the case with energy performance of buildings.

Benchmarking of energy efficiency demands for big number of calculations to obtain a bulk of data that can be scaled accordingly to the energy performance. Several lighting situations are combined with different road profiles, lighting system geometries and luminaire types including different lamps and quality of optics.

\section{Energy performance indicators}

Power density indicator (PDI) for an area divided into subareas can be calculated with the following formula:

$$
D_{P}=\frac{P}{\sum_{i=1}^{n} \overline{E_{i}} \cdot A_{i}}
$$

where

DP is the power density indicator (W.Ix-1.m-2);

$P$ is the system power of the lighting installation used to light the relevant areas $(\mathrm{W})$;

$\bar{E}_{i}$ is the calculated maintained average horizontal illuminance (Ix);

$\mathrm{Ai}$ is the size of the sub-area "i" lit by the lighting installation (m2);

$\mathrm{n}$ is the number of sub-areas to be lit.

Annual Energy Consumption Indicator (AECI) shall be calculated with the following formula:

$$
D_{E}=\frac{\sum_{j=1}^{m} P_{j} \cdot t_{j}}{A}
$$

where

$D_{E}$ is the annual energy consumption indicator for a road lighting installation (Wh. ${ }^{-2}$ );
$P_{j}$ is the operational power associated with the jth period of operation (W);

$t_{j}$ is the duration of jth period of operation profile when $\mathrm{Pj}$ is consumed, over a year $(\mathrm{h})$;

$A$ is the size of the area lit by the same lighting arrangement $\left(\mathrm{m}^{2}\right)$;

$m$ is the number of periods with different operational power $\mathrm{P}_{\mathrm{j}}$.

Examples of calculating both parameters are described in annexes of draft standard.

For calculations are needed input parameters:

System power of luminaires (W): Power of all components associated with the illuminated area and necessary for the functioning of the system shall be included in calculation, i.e. power of lamps, ballasts, control gears, drivers, lighting controls etc. If for calculation an elementary area of road section between two consecutive luminaires is considered, identical to the calculation field, only power of one of the luminaires is to be included (or half of the two luminaires).

Area as a target of illumination $\left(\mathrm{m}^{2}\right)$ : In general it can be an elementary area identical to the calculation field (see the previous comment) or it can be a full length of the lighting installation - in case of straight roads. Indicators are applicable also for any areas of regular or irregular shape like squares, parks, pedestrian walk zones etc.

Luminous parameter (Ix): The luminous parameter have to be in Ix for the all classes. For classes CE and $S$ is taken the maintaned average horizontal illuminance, and for $\mathrm{ME}$ classes is taken the maintaned illuminance calculated accordance with EN 13 201-3 in the same caltulated points as the maintaned luminance. At present, the calculating programs provide values of luminance and illuminance for the same calculating network.

Energy performance indicators are considered to calculating values, not normative, because calculating values represent the used technologies.

If we use for calculating indicators normative values, the comparison between lighting systems wouldn't be possible. 


\section{Sample calculation:}

Typical values of numerical indicators PDI and AECI have been developed base on a lot of sample calculations for the most common situations in public lighting.

In annexes of prEN $13201-5$ are showed the typical values of indicators depending on the type of lamps, luminaires, light classes, road profile and width of them.

At the figure 1 are showed all road profiles using in calculations, which were defined and publiched in [4].

A - infrastructure (road) for motorized traffic

B - infrastructure (road) for mixed traffic (motorized and pedestrian) without sidewalks

C - roadway and sidewalk parallel to the side of the lighting system (right trail)

D - roadway and sidewalk parallel to the side opposite the lighting system (left sidewalk)

$\mathrm{E}$ - roadway and parallel paths on both sides

F - roadway and parallel paths on both sides separated by the road green belt

$G$ - directionally divided two-lane road is without median

$\mathrm{H}$ - two-lane dual carriageway road is with a dividing strip

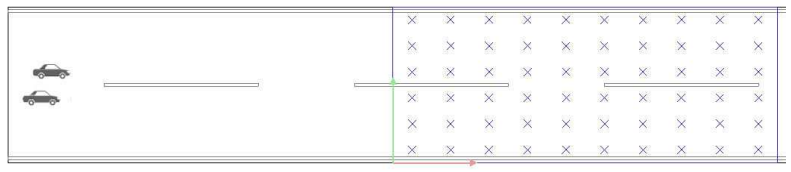

\section{$A: x R x R x$}

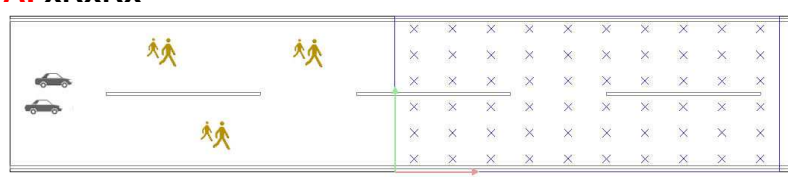

\section{$B: \operatorname{RxRx}$}

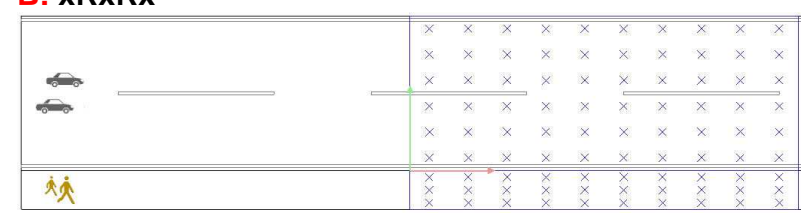

\section{C: $x R \times R F$}

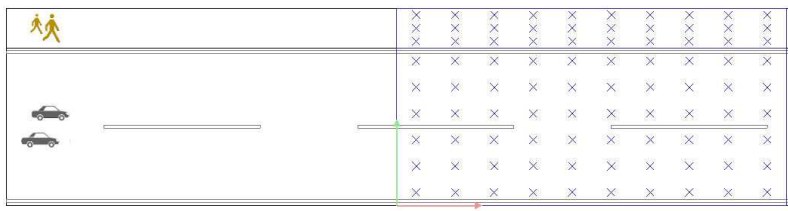

\section{D: FRxRx}

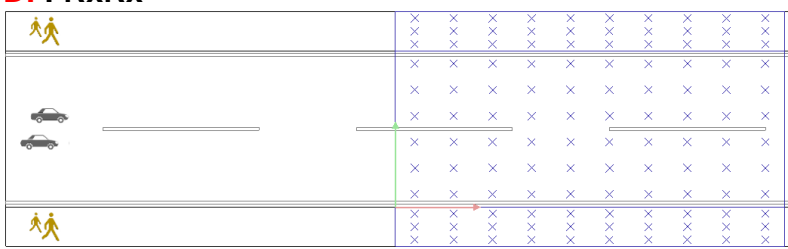

\section{E: FRxRF}

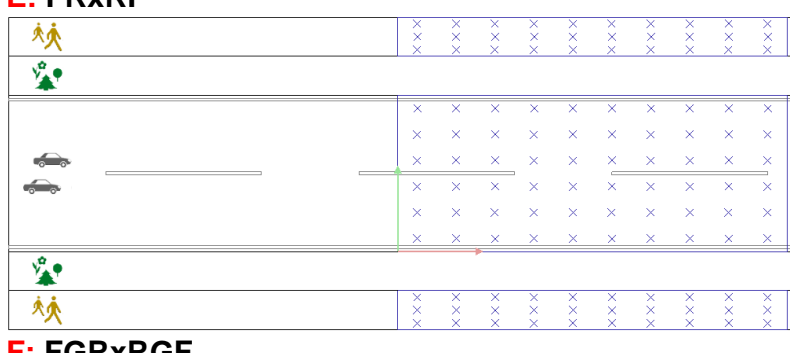

\section{F: FGRxRGF}
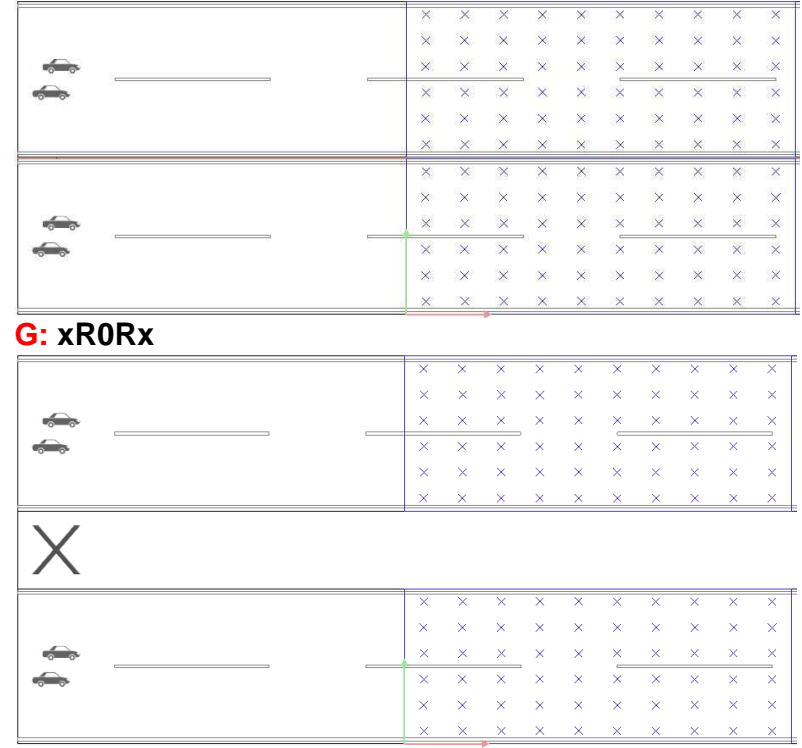

\section{$H: x R C R x$}

Fig.1. Road profiles used for sample calculations

Conditions for all sample calculations:

- width of sidewalks and green belts (if incorporated in the profile) is equal to $2 \mathrm{~m}$

- Maintenance factor is equal to 0.80 for all the types of light sources and luminaires

- road reflection properties the R3 table is considered

- The suspension height of the lamp is optimized in the range of 5 to $12 \mathrm{~m}$ (Step a: whole numbers)

- optimizing the spacing of poles and looked for in the range of 20 to $60 \mathrm{~m}$ (Step: $1 \mathrm{~m}$ )

- Arm overhang is ranged from 0 to $2 \mathrm{~m}$ (step: $0.5 \mathrm{M}$ )

- luminaires and boom have a $0^{\circ}$ angle

- Annual operating time of lighting is 4,000 hours at full wattage (at the figure 2.)

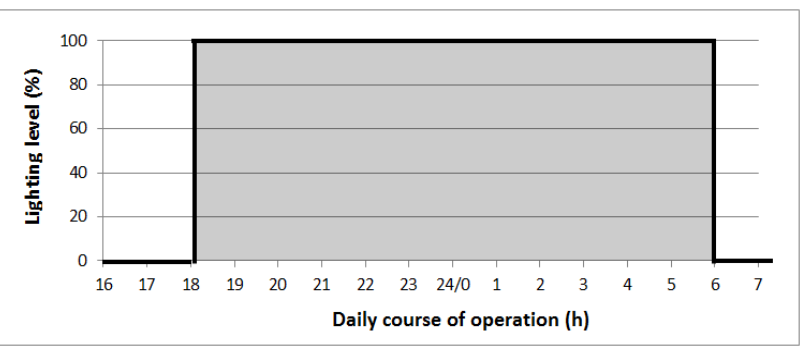

Fig.2. Full power operation time

In all cases were used single row lighting system. The priority of calculation was the longest distance between two poles to get the largest illuminated area. This optimalization have direct effect for the lowest values of numerical indicators. Suspension height and overhangs have only indirect effect for indicators.

For sample calculations are chosen different types of luminaires to included cheaper luminaires with simple diffuse optics and also more expensive luminaires with sofisticated optics parts with options of individually adjustment of position lamp. Choise of lamps include all using lamps in public lighting except flourescent lamps. All used luminaires are available at the present.

Sample calculations bave been extended to new luminaires, primarily focused on the newest LED luminaires and also luminaires with metalhalide, tubular sodium lamps. 
In the tables 1,2 are showed range of values for lamps. It is given enlarging used luminaires. The paper is focused on the results for class ME4 with A profile.

Table 1. Typical PDI values for road profile A

\begin{tabular}{|c|c|c|c|c|c|}
\hline ME4 & Mercury & MH & Sodium E & Sodium T & LED \\
\hline $8 \mathrm{~m}$ & 85 & $36-49$ & $39-45$ & $32-42$ & $20-25$ \\
\hline $7 \mathrm{~m}$ & 90 & $32-60$ & $41-48$ & $34-45$ & $18-24$ \\
\hline $6 \mathrm{~m}$ & 106 & $38-63$ & $49-57$ & $36-53$ & $23-27$ \\
\hline
\end{tabular}

Table 2. Typical $A E C l$ values for road profile $A$

\begin{tabular}{|c|c|c|c|c|c|}
\hline ME4 & Mercury & MH & Sodium E & Sodium T & LED \\
\hline $8 \mathrm{~m}$ & 4,7 & $2,1-2,7$ & $2,2-2,35$ & $1,25-2$ & $0,8-1,21$ \\
\hline $7 \mathrm{~m}$ & 5 & $1,8-3,1$ & $2,3-2,5$ & $1,5-2,35$ & $0,8-1,15$ \\
\hline $6 \mathrm{~m}$ & 5,5 & $2,1-3,5$ & $2,5-2,75$ & $1,65-2,5$ & $0,9-1,3$ \\
\hline
\end{tabular}

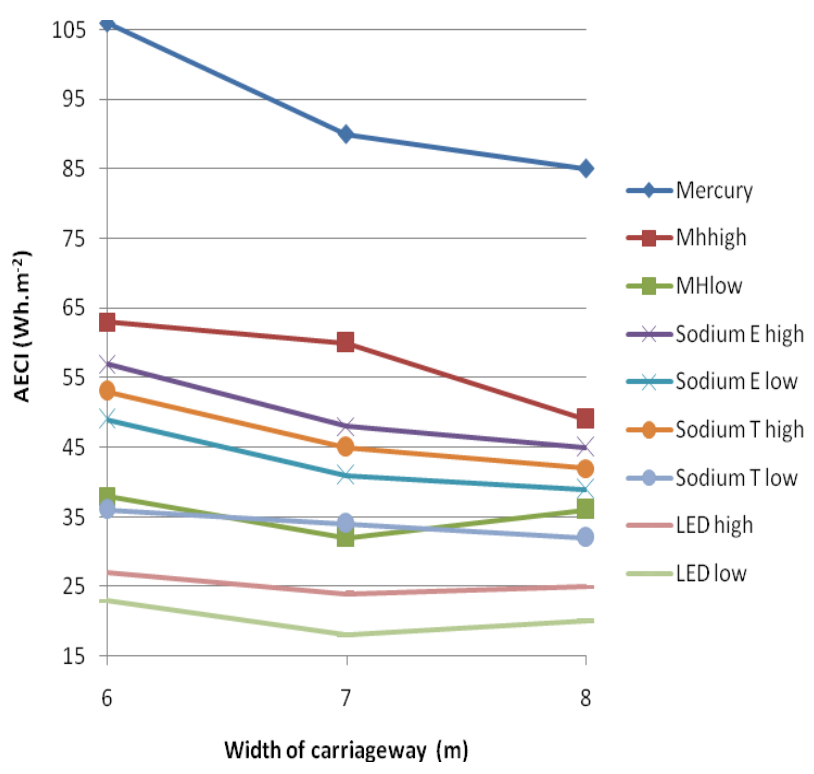

Fig.3. Road profiles used for sample calculations

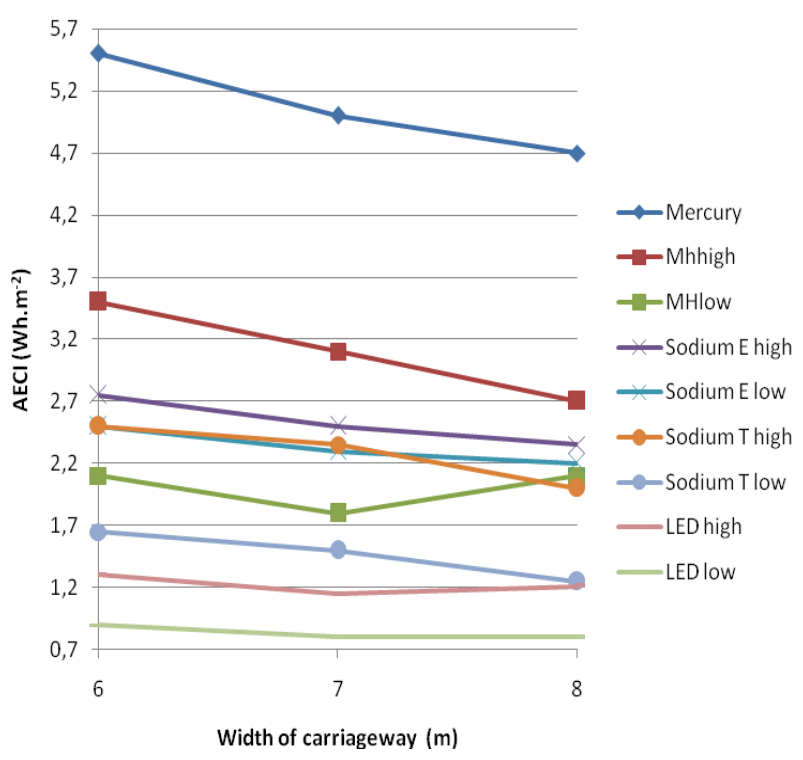

Fig.4. Road profiles used for sample calculations

\section{Conclusion}

At present, these results are preliminary. It is necesary to do more sample calculations with more luminaires for more road profiles with different width of cariagewas. In table 3 are showed values of PDI and AECl for energy classes. These values were published in [4], [3]. Proposal values for energy classes will modified, based on the next calculations.

Table 3. Typical PDI values for road profile A

\begin{tabular}{|l|c|c|}
\hline Energy Class & PDI & AECl \\
\hline & $\mathrm{mW} / \mathrm{x} / \mathrm{m}^{2}$ & $\mathrm{kWh} / \mathrm{m}^{2}$ \\
\hline A - B & $\leq 28$ & $\leq 1,4$ \\
\hline C - D & $28-34$ & $1,4-2$ \\
\hline E - F & $34-40$ & 2.3 \\
\hline G & $\geq 40$ & $\geq 3$ \\
\hline
\end{tabular}

\section{Acknowledgment}

This paper is supported by the agency VEGA MŠVVaŠ SR under Grant No.

VEGA 1/0988/12 „Energy efficiency of lighting systems in buildings“.

\section{REFERENCES}

[1] EN 15193:2007 Energy performance of buildings. Energy requirements for lighting

[2] EN 13201: Road lighting (group of standards), 2004

[3] prEN 13201-5:2014: Road lighting -Part 5: Performance requirments, 2014-07-23

[4] GAŠPAROVSKÝ, Dionýz - BARČíK, Michal - LIESKOVSKÁ, Linda. Hodnotenie energetickej hospodárnosti verejného osvetlenia normatívnym prístupom. In Kurz osvětlovací techniky XXXI : sborník odborného semináře. 1.vyd. Ostrava : Vysoká škola báňská - Technická univerzita v Ostravě, 2014, s. 133-144. ISBN 978-80-248-3553-2.

[5] GAŠPAROVSKÝ, D.: Calculation of the Operation Time of Road Lighting. In: Proceedings of CIE Centenary Conference "Towards a New Century of Light" : Paris, France, 15-16 April 2013. - Vienna : Commission Internationale de l'Eclairage, 2013. - ISBN 978-3-902842-44-2. - pp. 999 - 1008

[6] GAŠPAROVSKÝ, D.: Energy Performance Numerical Indicators of Public Lighting. In: "Svetlo - Light 2013", (Podbanské, Slovakia), 23.-25.10. 2013. - Bratislava : KONGRES Management s.r.o., 2013. - ISBN 978-80-89275-35-9. - pp. $291-301$

[7] PRACKI, P.: A proposal to evaluate road lighting energy efficiency. In proceedings: "Lumen V4", Bratislava : KONGRES Management S.r.o., 2012. ISBN 978-80-89275-32-8. - pp. 28 39

Authors: Ing. Michal Barčík, Slovenská technická univerzita $v$ Bratislave Fakulta elektrotechniky a informatiky, Ilkovičova 3, Bratislava, Slovak Republic,

e-mail: michal.barcik@stuba.sk

doc. Ing. Dionýz Gašparovský, PhD., Slovenská technická univerzita $v$ Bratislave Fakulta elektrotechniky a informatiky, Ilkovičova 3, Bratislava, Slovak Republic, e-mail: dionyz.gasparovsky@stuba.sk 